\title{
Consciousness and Language
}

Farrakhova Gulnaz Faizovna, Kazan Federal University, inter@kpfu.ru

Slavina Liliya Rustamovna, PhD, Kazan Federal University, slavinnalr@yandex.ru

Mustafina Jamila Nasyhovna, Dsc, PhD, Kazan Federal University, miss_jane@ mail.ru

Maklakova Evgeniya Mikhaylovna, PhD, Kazan Federal University, maklakovaem@mail.ru

Aydayeva Gunay Firuddinovna, PhD student, Kazan Federal University,

aydayevagf@yandex.ru

Garaeva Rimma Salavatovna, $\mathrm{PhD}$, Niznnekamsk Institute of Chemical Technology (the

branch of Kazan National Research Technological University), pd@nchti.ru

\begin{abstract}
This review article is devoted to the concept of consciousness in psycholinguistics. The characteristic features of interpretation in related sciences, the use in the process of interpretation of various methods of linguistic analysis are considered. The work covers the approaches to the concept of consciousness on the examples of works of domestic and foreign scientists. The necessity of using the concept of consciousness in combination with the concepts that operate in philosophy, psychology and psycholinguistics is revealed and substantiated. In conclusion, consciousness exists everywhere as a universal phenomenon and has a dual nature, because it is material and ideal.
\end{abstract}

Key words: Psycholinguistics, Consciousness, Language, Psychological Approach.

\section{Conciencia y lenguaje}

\section{Resumen}

Este artículo de revisión está dedicado al concepto de conciencia en psicolingüística. Se consideran los rasgos característicos de la interpretación en ciencias relacionadas, el uso en el proceso de interpretación de varios métodos de análisis lingüístico. El trabajo cubre los enfoques del concepto de conciencia en los ejemplos de trabajos de científicos nacionales y extranjeros. La necesidad de utilizar el concepto de conciencia en combinación con los conceptos que operan en filosofía, psicología y psicolingüística se revela y se justifica. En conclusión, la conciencia existe en todas partes como un fenómeno universal y tiene una naturaleza dual, porque es material e ideal.

Palabras clave: Psicolinguiística, Conciencia, Lenguaje, Enfoque Psicológico.

\section{Introduction}


Proceeding from the modern interpretations of the concept, consciousness is a mechanism that reacts to reality in the form of emotional signals and feelings. Thus, consciousness can include the following components: perception, thoughts, imagination, and self-awareness. At different times it is able to act as a certain type of mental state, a way of perception and relationships with others. And this philosophical definition is intertwined with the psychological approach to understanding the phenomenon of consciousness. The possibilities of the human brain determine the conscience of his own being through the prism of his relation to the surrounding world, to other people, and to himself. In the opinion of Talbot (2004), consciousness provides human with facilities by acting as the means of the repletion of cognitive and communicative needs. Consciousness, above a complex system, promotes development and self-development, models the world and transforms it into activity. The unit of consciousness, according to Tarasov (1993), is that in what and by what means the consciousness exists, i.e. a system of verbal meanings, as well as a system of multilevel communicative means serving these values.

Very noteworthy are the conclusions of the neurophysiologist and the physicist Talbot, who proposed the following interpretation to the notion of consciousness: "the whole material world is a giant hologram, where even the tiniest part of the image consists of the information about the general picture of being, where everything is interdependent and interrelated" (Talbot, 2004: 12). The article offers a brief critical review of the main theories in the study of the phenomenon of consciousness. The framework of the article is focused by the authors on bibliography and scientific research, one way or another leading to the notion of linguistic consciousness.

\section{Methodology}

Interpretations of understanding the consciousness are determined by the world outlook and methodological representation, the choice of different aspects and objectives of the study. A critical review of the definition of consciousness and an attempt to identify and offer the research classification is realized by using different methods and approaches. Methods for studying literature on resolution and theoretical analysis are used to comprehend theoretical postulates and models developed in different directions of science. Inductive and deductive methods, the classification of modeling of different levels of understanding and systems adequately reflecting the notion of the phenomenon of consciousness are utilized within the review.

\section{Discussion}

At the moment there is no single definite concept for consciousness. There are many interpretations in which this concept is compared with the linguistic world image, with verbal behavior, with perceptual abilities, with value-semantic, emotional components. From a philosophical point of view, consciousness is treated as the ability of the brain to reflect objective reality in sensory or logical images. Consciousness is not just a generalized and evaluative image in general, it is oriented towards the reflection and transformation of the world. The first thing that is given to a person is consciousness. A person perceives everything through the prism of his consciousness, and everything is in direct dependence on it. The philosophical approach to consciousness concentrates its attention on what the latter represents as an intermediary between the inner world of person and 
external reality. The British philosopher Priest (2000) in his work reviews primary approaches on the problems of consciousness, expressed in the history of world philosophy. The problem of consciousness is given great attention. Even in ancient Greece philosophers raised the problem of consciousness. They regarded consciousness as a kind of synthesis of thinking and soul. So, Democritus, Socrates, Plato regarded the soul as a special entity.

The epoch of modern times brought a new direction to the study of consciousness. Consciousness is now not treated as a soul, but as a person's cognitive ability. Descartes understands consciousness as a product of the inner development of thinking, J. Locke and T. Hobbes - as a result of external influences. Philosophy of the 19th century changes the foreshortening to understanding this phenomenon. Those times philosophers talk about the dependence of the conscious and the unconscious (Nietzsche, Shoppehauer). In philosophy, the following concepts (Table 1) of consciousness have developed and retain their significance in modern culture.

Table 1. Consciousness concepts

\begin{tabular}{|l|l|}
\hline \multicolumn{1}{|c|}{ Philosophy concept } & Description \\
\hline $\begin{array}{l}\text { The objective-idealistic } \\
\text { concept }\end{array}$ & $\begin{array}{l}\text { The spirit (consciousness) and matter (body) are two independent but } \\
\text { complementary substances. }\end{array}$ \\
\hline Hilozoism & All matter is animated or at least has prerequisites for thinking. \\
\hline $\begin{array}{l}\text { The subjective-idealistic } \\
\text { concept }\end{array}$ & A person's consciousness as a self-sufficient entity. \\
\hline Materialism & Identifies consciousness with material formations in the human brain. \\
\hline Sociologizing & The consciousness is in absolute dependence on the external environment \\
\hline Dialectical materialism & $\begin{array}{l}\text { Consciousness is the unity of the material and ideal, objective and subjective, } \\
\text { biological and social. }\end{array}$ \\
\hline
\end{tabular}

Proceeding from the modern interpretations of the concept, consciousness is a mechanism that reacts to reality in the form of emotional signals and feelings. Thus, consciousness can include the following components: perception, thoughts, imagination, and self-awareness. At different times it is able to act as a certain type of mental state, a way of perception and relationships with others. And this philosophical definition is intertwined with the psychological approach to understanding the phenomenon of consciousness.

The psychological approach to consciousness consists in elucidating the mechanism of its functioning, revealing the natural and social components in it. Consciousness helps a person to have a propitious existence in real life as by means of consciousness a person learns, communicates, becomes able to work, acts in a social environment. With the help of consciousness a person controls his/her behavior: the signals of the external and internal environment are regulated by consciousness. Marx noted that: "the way consciousness exists and something exists for it is knowledge" (Marx, 1844: 19). Hence follows: consciousness includes the whole spectrum of psychological characteristics - sensation, perception, memory, and thinking. In her article Balashova notes: "Man is different from animals in that he can evaluate himself, his actions, and his behavior" (Balashova, 2004: 18). In other words, consciousness is the ability to distinguish between subject and object. Maslow (1999) defines consciousness as the highest level of mental reflection of objective reality, understands this concept as the highest level of self-regulation, and notes that it is inherent only to man as a social being. The Spanish scientist neurophysiologist, psychiatrist Delgado in his work puts forward postulates about consciousness, which read: "at the moment of the child's birth, there is no individual consciousness; consciousness cannot arise without the inflow of sensory information; man is not born free, heredity and education prevail over him" (Delgado, 
1971: 18). Further, proceeding from this, we can assume that, when evaluating one's behavior, a person comes to some conclusions, which are reduced in the next stage to achieve certain goals. The goal-setting activity of man is another link that reveals the concept of consciousness from a psychological point of view.

In psychology, consciousness is one of the elements that explains the mechanism of human behavior, along with will, attention, emotions and memory. Psychologists Slobodchikov and Isaev write: "... consciousness is not knowledge about being and is not relation to it, but self-conscious being" (Slobodchikov and Isaev, 1995: 15). Consciousness in various psychological schools (Table 2) was interpreted in different ways.

Table 2. Consciousness concepts in psychology

\begin{tabular}{|l|l|}
\hline \multicolumn{1}{|c|}{ Psychological concept } & Description \\
\hline Structuralists & The nature of consciousness is in the very consciousness itself. \\
\hline Functionalists & The nature of consciousness is derived from biological needs \\
\hline The activity approach & The unity of consciousness and activity \\
\hline Behaviorism & Consciousness = internal behavior \\
\hline Cognitive psychology & Consciousness is explained by the logic of the process of cognition \\
\hline Cultural-historical psychology & Consciousness is a person's reflection of reality. \\
\hline
\end{tabular}

It turns out that consciousness in psychology is a social product, because it should be taken into account that consciousness is the result of training, communication, work activity of a person in a social environment, successful interaction in real life. Thus, consciousness is formed under the influence of socio-historical conditions in the labor activity of human. Consciousness is first and foremost a body of knowledge. Violation of any of the cognitive processes leads to a disorder of consciousness. Thanks to the advanced reflection, the person reveals the cause-effect relationships, foresees the future, sets a goal, takes into account the motives and makes volitional decisions, makes the necessary adjustments, overcomes difficulties. By his/her activities, a person actively influences the world around him. A person's consciousness turns out to be in his activity. The cause and word of a person is a manifestation of his consciousness.

Formed in the middle of the 20th century, scientific psycholinguistics began to study the language as a phenomenon of the psyche, its role in the formation of consciousness. Within the framework of psycholinguistic science, scientists often distinguish linguistic consciousness. Thus, home and foreign psycholinguists and linguists Osgood et al. (1957), Luria (2003), Bernstein (1967), Piaget (1951), Baudouin and Ivan (2003), and others adhere to the direction to bridge the gap between linguistic and psychological approaches, to integrate knowledge and a more complete and thus more adequate understanding of the concept of linguistic consciousness.

The concept of linguistic consciousness is very vague, and this is mentioned by Spirkin: "When we use the term"(1988: 10) linguistic consciousness, we continually fall into the trap of the magic of words: if something is linguistic, then it must be adequately transmitted by linguistic means that seem self-sufficient, completely amenable to analysis and description from the standpoint of the corresponding science-linguistics; if it is a question of consciousness, then it seems to be selfevident that nothing unconscious (besides - not verbalized!) is initially not allowed .... G. Guillaume in his work Principles of Theoretical Linguistics emphasizes that when studying the notion of 
consciousness, it is necessary to consider a more specific concept of linguistic consciousness, since the language realizes the mental. Linguistic consciousness is brought closer to such concepts as the language picture of the world, the strategy and tactics of speech behavior. As Spirkin noted:

We dismember the world, organize it into concepts and distribute the values in this way, and not otherwise, mainly because we are participants in an agreement that prescribes such a systematization. This agreement is valid for a certain language collective and is fixed in the system of models of our language (1988: 12).

In any case, linguistic consciousness is realized in speech behavior. Often, linguistic consciousness is identified with speech behavior. Speaking about the linguistic consciousness of a person, we mean such features of speech behavior that determine a number of factors: gender, age, social status, cultural status, worldview, psycho-type, memory, thinking, communicative situation in general, characteristics of character, etc. According to Rubinshtein (2005), speech along with attention, memory and thinking becomes an end-to-end psychic process that permeates all spheres of the individual: intellectual (cognitive), strong-willed, emotional. As we know, linguistic consciousness consists of the conscious and the unconscious, since in the processes of understanding the text or speech both conscious actions and unconscious mechanisms are involved. This is mentioned by Rubinshtein:

The term linguistic consciousness combines two different entities: consciousness is a psychic phenomenon of non-material nature (it cannot be measured by spatial features, it is not spatial, cannot be heard and seen) - and the material phenomenon of spoken or written speech, as well as the physiological process of the formation of verbal language ties (2005: 18).

In determining the language consciousness it is important to distinguish between the terms consciousness, world view, thinking, because each of the above concepts serves as a designation for various phenomena. In this connection Ivanova believes that:

Every natural language reflects a certain way of conceptualizing (perceiving and organizing) the world, while meanings expressed in language, form a unified system of views that represents a kind of collective philosophy that is imposed on all native speakers of the language as mandatory (1994: 22).

The term consciousness is considered to be a reflexive psychological activity, including perceptions, processing perceived and forming an integral picture of the world, containing knowledge and relations, objects and the subject itself in relation to them. As can be seen from the above definition, reflection is the ratio of the subject to the object and occupies a key place in this case, since the subject -i.e. an observer included in the world picture - fixes the space-time and a number of other characteristics of the object from a subjective position, from his point of view. In this regard, the interest in the phenomenon of linguistic consciousness is explained, since there are many different positions of the subject in the perception of information and the embodiment of knowledge by the means of the native language, and any position of the individual is always conditioned by culture, language, and society. From this, it follows that the picture of the world also appears as a result of the functioning of linguistic consciousness, but at the same time forms the basis for successfully navigating in the communicative situation in the perception of speech.

\section{Conclusion}


Thus, the world view is the totality of ideas about the structure of the world, the replaced real world in consciousness, the projection of reality. The conductor between the real world and consciousness is language, without which the existence of consciousness is impossible a priori. In the scientific community, consciousness is considered to be the highest function of the brain that is unique to human and connected with speech, consisting of a generalized and purposeful reflection of reality, in the mental construction of activity and the anticipation of its results, in the rational regulation and self-control of human behavior. Scientific studies of the phenomenon of consciousness sharply raise the question of an interdisciplinary approach, of the development of a generally understandable language of description and explanation, of the correlation of various methods (as is clearly seen in the development of cognitive sciences that seek to unify in conceptual terms concepts and methods of psychology, neurophysiology, linguistics, informatics, computer science). As a universal phenomenon, consciousness exists everywhere. By its nature, consciousness has a dual nature, because it is material and at the same time ideal. There is every reason to believe that the views of such sciences as philosophy, psychology and psycholinguistics find common ground in the question of the nature of consciousness. This approach to the concept of consciousness reveals the prospects for considering the question of the emergence of this concept in an interdisciplinary perspective.

\section{References}

BALASHOVA, E. 2004. Concepts of love and hatred in the Russian and American language consciousness: the Dissertation of the candidate of philological sciences-Saratov. P. 262. Russia.

BAUDOUIN, C., and IVAN, A. 2003. New Illustrated Encyclopedia. Book. 3. The Great Russian Encyclopedia. pp. 27-28. Russia.

BERNSTEIN, N.A. 1967. The co-ordination and regulation of movements. Pergamon Press. Oxford. UK.

DELGADO, H. 1971. Brain and consciousness. Mir. p. 263. Russia.

IVANOVA, A. 1994. Consciousness and thinking. M. Russia.

LEONTIEV, A. 1981. Biological and social in the human psyche. Problems of development of the psyche. Publishing house of Moscow University. pp. 193-218. Russia.

LURIA, A. 2003. Foundations of Neuropsychology. Textbook for students of higher educational institutions. Publishing Center Academy. p. 384. Russia.

MARX, K. 1844. Economical and philosophical manuscripts. Engels F. Works. Vol. 42. p. 165. Russia.

MASLOW, A. 1999. Motivation and personality. SPb: Eurasia. p. 478. Russia.

OsGoOd, C., SUCI, G., and TANnEnBAUM, P. 1957. The Measurement of Meaning. University of Illinois Press. Illinois. USA.

PIAGET, J. 1951. The Psychology of Intelligence. Routledge and Kegan Paul. London. UK. 
PRIEST, S. 2000. Theory of Consciousness. Translation from English. Idea Press-House Intellectual. p. 287. Russia.

RUBINSHTEIN, S. 2005. Fundamentals of General Psychology. St. Petersburg: Peter. Russia.

SLOBODCHIKOV, V., and ISAEV, E. 1995. Fundamentals of psychological anthropology. Human psychology: Introduction to the psychology of subjectivity. Textbook for high schools. School-Press. p. 384. Russia.

SPIRKIN, A. 1988. Fundamentals of Philosophy: A Textbook for High Schools. Politizdat. p. 592. Russia.

TALBOT, M. 2004. Holographic Universe. Translation from English. M.: Sofia Publishing House. p. 368. Russia.

TARASOV, E. 1993. The Forms of Existence of Consciousness. Language and Consciousness: Paradoxical Rationality. RAS. pp. 86-97. Moscow. Russia. 